\title{
PROSES PROGRAM DESA PERTANIAN ORGANIK (Studi Kasus Pada Kelompok Tani Sarinah Organik, Desa Bumiwangi, Kecamatan Ciparay, Kabupaten Bandung, Provinsi Jawa Barat)
}

\section{LUTFHI JUANSAH*, ANNE CHARINA, RANI ANDRIANI BUDI KUSUMO, PANDI PARDIAN}

Program Studi Agribisnis, Departemen Sosial Ekonomi Pertanian, Fakultas Pertanian, Universitas Padjadjaran

*Email: lutfhi17@gmail.com

\begin{abstract}
ABSTRAK
Pada tahun 2016, pemerintah Indonesia mengeluarkan program pengembangan 1.000 desa pertanian organik. Kelompok tani Sarinah Organik merupakan kelompok tani yang terlibat secara langsung dalam pelaksanaan program desa pertanian organik tersebut. Tujuan dari penelitian ini adalah untuk mengetahui bagaimana pelaksanaan program desa pertanian organik yang dilakukan oleh Kelompok Tani Sarinah Organik dan kendala apa saja yang muncul selama pelaksanaan program. Penelitian ini menggunakan metode deskriptif kualitatif dengan teknik pendekatan studi kasus. Dalam penelitian ini digunakan model analisis data Miles and Huberman. Hasil penelitian menunjukan bahwa kelompok tani Sarinah Organik telah melaksanakan semua tahapan program desa pertanian organik. Hal ini dilihat dari bertambah luasnya lahan sawah tersertifikasi sebanyak 18,337 hektar dan jumlah petani organik sebanyak 44 orang. Sementara itu, kendala yang muncul selama pelaksanaan program adalah kurangnya pengetahuan petani tentang sistem pertanian organik, kendala dalam menentukan calon petani organik, kendala dalam menentukan wilayah pengembangan organik, dan tidak berjalannya kegiatan pembuatan pupuk dan pestisida organik yang berkelanjutan.
\end{abstract}

Kata kunci: Pengembangan, Desa, Pertanian Organik

\section{ABSTRACT}

In 2016, Indonesia government released program of 1000 villages development of organic farming. Sarinah Organik farmer group was one of farmer groups directly involved in implementing that village program of organic farming. The purpose of this study was to find out how the implementation of organic farming village program conducted by the organic Sarinah farmer group and what obstacles emerged during the program implementation. This study used method of qualitative descriptive through approach technique of case study. In this study used data analysis model Miles and Huberman. Result of study indicated that Sarinah Organik farmer group have done all the steps of organic farming village program. This was seen from the increased of certified rice field area by 18.337 hectares and number of organic farmers by 44 people. Meanwhile, obstacles that arise during the implementation of the program were the lack of farmer's knowledge about organic farming system, the obstacles in deciding prospective organic farmers, in deciding region of organic farming development, and the failure of sustainable fertilizer and organic pesticide producing activity.

Keywords: Development, Village, Organic Farming

\section{PENDAHULUAN}

Beras menjadi makanan pokok untuk mayoritas penduduk di Indonesia. Dalam upaya memenuhi kebutuhan beras, pada masa orde baru pemerintah menerapkan kebijakan revolusi hijau.

Revolusi ini ditandai dengan adanya teknologi pertanian terkait pemuliaan tanaman (benih unggul), pemupukan kimia, serta pemberantasan hama dan 
penyakit secara intensif dengan menggunakan pestisida kimia. Kebijakan ini merupakan program nasional untuk meningkatkan produksi pangan.

Meskipun mendapatkan hasil yang memuaskan, penggunaan bahan kimiawi dalam jangka panjang menimbulkan berbagai dampak negatif. Dampak bagi lingkungan diantaranya menyebabkan penurunan produktivitas tanah dan rusaknya ekosistem. Selain pencemaran lingkungan, penggunaan pestisida dapat menyebabkan berbagai penyakit bagi konsumen karena sisa zat kimia yang ikut masuk ke dalam tubuh bersamaan dengan makanan yang dikonsumsi (Kementerian Pertanian, 2016).

Pemerintah mulai membuat kebijakan pertanian yang lebih ramah lingkungan. Sistem pertanian organik dinilai menjadi solusi dalam permasalahan yang dihadapi. Proses pengembangan pertanian organik di Indonesia dimulai pada tahun 2001.

Tahapan pengembangan pertanian organik dimulai dengan sosialisasi. Kemudian dilanjut dengan pembuatan regulasi dan pemberian bantuan teknis. Pada tahun 2004, pemberian bantuan teknis dibarengi dengan proses sertifikasi organik. Kemudian pada tahun 2005 diharapkan semua bentuk infrastruktur pendukung pertanian organik baik fisik maupun kelembagaan telah terbentuk. Sehingga pada tahun 2006 hingga 2010 akan dilanjutkan dengan pengembangan industrialisasi dan perdagangan. Dengan adanya pengembangan ini, Indonesia diharapkan mampu menjadi salah satu produsen dan eksportir pangan organik.

Salah satu agenda program pemerintah dalam NAWACITA adalah peningkatan kedaulatan pangan dengan sasaran "Pengembangan 1000 Desa Pertanian Organik". Program pengembangan desa pertanian organik mulai diterapkan pada tahun 2016. Pengembangan 1000 desa pertanian organik ini akan dilaksanakan pada 4 (empat) subsektor komoditi, yaitu tanaman pangan 600 desa, tanaman hortikultura 250 desa, tanaman perkebunan dan peternakan 150 desa. Lokasi pelaksanaan program ditentukan atas dasar pertimbangan potensi lahan dan aksesibilitas wilayah yang dimiliki.

Sasaran desa organik tanaman pangan untuk provinsi Jawa Barat terbagi atas 50 desa yang tersebar di berbagai wilayah (Rencana Strategi Kementerian Pertanian 2015-2019). Pada tahun 2016 di wilayah Kabupaten Bandung, desa yang mendapatkan program ini adalah Desa Ciapus, Desa Bumiwangi dan Desa 
Serangmekar. Sedangkan untuk tahun 2017, desa yang mendapatkan program adalah Desa Wargamekar, Desa Ciheulang dan Desa Sugihmukti (Dinas Pertanian, Perkebunan dan Kehutanan Kabupaten Bandung, 2018).

Dalam upaya terwujudnya program pengembangan desa pertanian organik, kelompok tani memiliki peran sebagai penerima manfaat dari bantuan yang diberikan. Menurut hasil wawancara yang dilakukan kepada Ibu Anni Damayanti selaku pihak dari Dinas Pertanian Kabupaten Bandung, syarat utama untuk mendapatkan program desa pertanian organik adalah kelompok tani penerima manfaat sudah menerapkan sistem pertanian organik baik telah tersertifikasi maupun belum.

Kelompok Tani Sarinah Organik ditetapkan sebagai kelompok tani penerima manfaat karena sudah memenuhi syarat dan dianggap mampu untuk mengembangkan pertanian organik di wilayah Desa Bumiwangi dan sekitarnya. Kelompok Tani Sarinah dipilih karena kelompok tani ini merupakan kelompok tani yang telah mandiri secara administratif dan sudah memiliki sertifikasi organik yang dikeluarkan oleh lembaga sertifikasi organik Indonesian Organic Farming
Certification (INOFICE) pada 7

November 2011.

Selain mendapatkan sertifikasi organik nasional, Kelompok Tani Sarinah telah mendapatkan sertifikasi organik yang dikeluarkan oleh lembaga sertifikasi internasional Control Union (CU) pada tanggal 13 November 2017. Jenis sertifikasi yang didapat adalah United States Departement of Agriculture (USDA). Dengan adanya sertifikat ini, produk dari Sarinah Organik telah diakui dan dapat diekspor ke negara Amerika Serikat.

Dengan prestasi dan pencapaian yang telah dimiliki, Dinas Kabupaten Bandung menaruh harapan besar pada Kelompok Tani Sarinah Organik untuk mengembangkan pertanian organik khususnya komoditas padi di wilayah Kabupaten Bandung dan sekitarnya. Dukungan penuh diberikan dengan ditunjuknya secara langsung Kelompok Tani Sarinah Organik sebagai penerima manfaat dari program desa pertanian organik pada tahun 2016. Dengan ditetapkannya Kelompok Tani Sarinah Organik sebagai kelompok tani penerima manfaat program, diharapkan jumlah produksi beras organik dapat bertambah. Target pengembangan luas lahan organik yang harus dicapai adalah 20 ha. Kondisi 
lahan di Desa Bumiwangi yang memungkinkan untuk dikembangkan secara organik hanya ada sekitar 8 ha. Oleh karena itu, Kelompok Tani Sarinah Organik mencoba mengembangkan lahan sawah organik seluas 12 ha di Desa Ciheulang.

Dalam pelaksanaan program desa pertanian organik, terdapat beberapa tahapan yang harus dilakukan. Selama proses pelaksanaan program di lapangan, kemungkinan ada kendala yang muncul. Kendala yang mungkin muncul terdapat pada proses pelaksanaan tahapan berikut:

1) Sosialisasi program.

2) Persiapan pelaksanaan seleksi calon kelompok sasaran dan calon lokasi.

3) Pengadaan dan penyaluran bantuan program.

4) Kebenaran dan ketepatan pemanfaatan dana bantuan program.

5) Evaluasi dan pelaporan.

Berdasarkan kondisi tersebut, penulis tertarik untuk mengkaji lebih dalam terkait dengan bagaimana proses pelaksanaan program desa pertanian organik yang dilakukan oleh Kelompok Tani Sarinah Organik dan kendala apa saja yang yang muncul selama proses program desa pertanian organik.

Adapun tujuan penulis mengadakan penelitian adalah untuk mengetahui:
1. Pelaksanaan program Desa Pertanian Organik yang dilakukan oleh kelompok Tani Sarinah Organik sebagai kelompok tani penerima manfaat.

2. Kendala yang muncul dalam pelaksanaan program Desa Pertanian Organik.

\section{METODE PENELITIAN}

Objek yang dikaji pada penelitian ini adalah proses program desa pertanian organik dan kendala yang muncul selama pelaksanaan program. Penelitian ini dilaksanakan di Kelompok Tani Sarinah Organik di Kecamatan Ciparay, Kabupaten Bandung. Pemilihan lokasi ini dilakukan secara sengaja (purposive) dengan pertimbangan Kelompok Tani Sarinah Organik merupakan kelompok tani penerima manfaat program desa pertanian organik. Kelompok Tani Sarinah Organik juga telah berhasil mengembangkan padi organik dan memiliki sertifikat organik baik nasional maupun internasional.

Desain penelitian yang digunakan dalam penelitian ini adalah desain kualitatif. Menurut Sugiyono (2012), desain kualitatif adalah metode penelitian yang bertujuan untuk meneliti keadaan objek alamiah dengan posisi dimana 
peneliti merupakan instrumen kunci, analisis data bersifat induktif, teknik pengumpulan data gabungan, dan hasil penelitian ditentukan pada makna dibanding generalisasi.

Teknik penelitian yang digunakan adalah metode studi kasus (case study). Menurut Silalahi (2003), metode studi kasus adalah metode yang digunakan untuk mempelajari secara intensif atau mendalam dari suatu anggota kelompok sasaran suatu objek penelitian.

Teknik pengumpulan data dan informasi terbagi ke dalam tiga cara, yaitu wawancara, observasi, serta studi kepustakaan. Data primer didapatkan dari hasil wawancara langsung dengan informan kunci dan informan pendukung serta di dapatkan dari hasil observasi langsung di lapangan, sedangkan data sekunder di dapatkan dari hasil telaah studi kepustakaan baik dari jurnal ilmiah maupun yang berasal dari internet.

Untuk mengetahui bagaimana pelaksanaan program desa pertanian organik yang dilakukan oleh Kelompok Tani Sarinah Organik dan kendala yang muncul, teknik analisis yang digunakan dalam penelitian ini adalah dengan teknik analisis deskriptif. Analisis deskriptif merupakan metode penelitian yang menggambarkan suatu fenomena, kondisi tentang objek penelitian, serta keadaan yang sebenarnya terjadi di lapangan yang dilaksanakan dengan cara mengumpulkan, menyajikan, dan menganalisis data berdasarkan fakta yang ada di tempat penelitian. Data sekunder dan data primer digambarkan dalam bentuk narasi dan diringkas dalam bentuk tabel, bagan, diagram, ataupun grafik, sehingga disajikan dengan bentuk yang mudah dipahami.

Di dalam penelitian ini, model analisis Miles and Huberman digunakan untuk menganalisis proses pelaksanaan program desa pertanian organik. Miles and Huberman dalam Sugiyono (2012) mengemukakan bahwa aktivitas dalam data kualitatif dilakukan secara interaktif dan berlangsung secara terus menerus sampai tuntas, sehingga datanya sudah jenuh. Langkah-langkah dari model analisis Miles and Huberman ialah:

1) Reduksi data (Data reduction)

Reduksi data dilakukan untuk merangkum, memilih hal yang pokok, memfokuskan pada hal-hal penting, mencari tema dan pola serta membuang yang tidak perlu.

Reduksi data yang dilakukan dalam penelitian ini dimulai dari tahap pengumpulan data, yaitu tahap wawancara dengan informan yang dipilih dari pihak 
pelaksana program yaitu Dinas Pertanian

Kabupaten Bandung, Penyuluh, Fasilitator, Kelompok Tani Sarinah Organik. Wawancara terfokus pada halhal penting atau hal pokok yang dilakukan oleh semua informan dalam pelaksanaan program desa pertanian organik.

2) Penyajian data (Data display)

Tahapan penyajian data dilakukan agar data dan informasi yang didapatkan dapat lebih terorganisir dan tersusun dalam pola hubungan yang jelas sehingga lebih mudah untuk dipahami. Penyajian data dapat dilakukan dalam bentuk grafik, matrik, tabel, chart dan sejenisnya.

Data yang disajikan dalam penelitian ini berupa kutipan-kutipan hasil wawancara dengan semua informan yang telah dipilih. Untuk mempermudah memahami bagaimana pelaksanaan program desa pertanian organik yang dilakukan oleh Kelompok Tani Sarinah Organik dan kendala yang muncul selama program berjalan, data hasil penelitian juga di sajikan dalam bentuk gambar dan tabel.

3) Penarikan Kesimpulan (Conclusion Drawing) / Verifikasi (Verification)

Kesimpulan adalah tahap akhir dalam proses analisa data. Dilakukan verifikasi penarikan kesimpulan dengan tujuan untuk menjawab identifikasi masalah yang telah ditetapkan.

Kesimpulan dari penelitian ini yaitu dilihat dari bagaimana proses pelaksanaan program desa pertanian organik yang dilakukan oleh Kelompok Tani Sarinah Organik dan kendala muncul selama pelaksanaan program berlangsung. Sehingga dapat dilihat hasil dari program desa pertanian organik yang dilaksanakan oleh Kelompok Tani Sarinah Organik.

\section{HASIL DAN PEMBAHASAN}

Program Desa Pertanian Organik di Kelompok Tani Sarinah Organik

Terdapat 5 tahapan yang dijelaskan di dalam buku "Petunjuk Teknis Pengembangan Desa Organik Padi” yang dikeluarkan oleh Direktorat Jenderal Pangan pada tahun 2016. Waktu pelaksanaan tahapan program tersebut akan dijelaskan pada Tabel 1.

Tabel 1. Waktu Pelaksanaan Program Desa Organik Padi

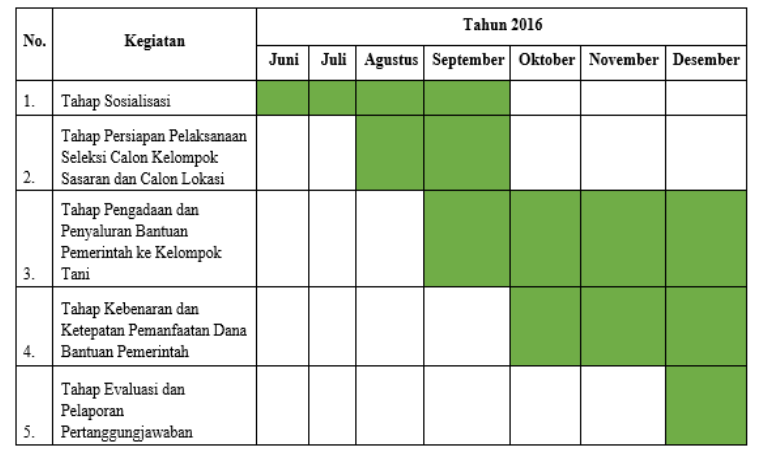


Berdasarkan Tabel 1, berikut adalah penjelasan mengenai tahapan-tahapan program Desa Pertanian Organik Padi:

\section{Tahap Sosialisasi}

Sosialisasi program desa pertanian organik dilakukan oleh tim pengarah/pembina dari pusat/provinsi dan tim teknis dari kabupaten. Proses sosialisasi dimulai pada bulan Juni 2016. Tahap sosialisasi dimulai dengan penyampaian informasi ke wilayah Kabupaten Bandung.

Sosialisasi dilakukan oleh penyuluh kepada setiap kelompok tani yang ada di wilayah Kabupaten Bandung. Kemudian kelompok tani diminta untuk membuat dan mengajukan proposal bantuan program. Setelah Surat Keputusan (SK) bantuan program turun, dilakukan sosialisasi kembali bagi kelompok tani mana saja yang ditunjuk sebagai penerima manfaat. Pada tahun 2016, hanya ada 3 kelompok tani penerima manfaat yang mendapat bantuan program ini yaitu Kelompok Tani Sarinah Organik, Kelompok Tani Mekarsari 4, dan Kelompok Tani Bina Usaha Cikopo.

\section{Tahap Persiapan Pelaksanaan \\ Seleksi Calon Kelompok Sasaran dan Calon Lokasi}

Setelah kelompok tani mengirimkan proposal untuk mendapatkan bantuan,
Dinas Pertanian menyeleksi dan memilih Calon Penerima (CP) dan Calon Lokasi (CL) yang dianggap mampu memanfaatkan bantuan program dengan baik. CP/CL yang diutamakan adalah desa/poktan yang ada sudah menjalakan sistem organik sebelumnya..

Selain berdasarkan proposal, usulan dari penyuluh dan tim teknis dari kabupaten menjadi pertimbangan dalam menentukan desa/poktan mana yang mendapatkan program desa organik. Setelah mendapat data dari usulan dan proposal, dilakukan seleksi dan verifikasi. Kemudian ditetapkan desa mana saja yang mendapat bantuan program ini.

Kelompok Tani Sarinah Organik merupakan salah satu kelompok tani yang mendapatkan program desa pertanian organik hasil dari usulan petugas lapangan. Kelompok tani Sarinah ditunjuk langsung oleh Dinas pertanian untuk mengembangkan pertanian organik di Desa Bumiwangi dan sekitarnya.

\section{Tahap Pengadaan dan Penyaluran \\ Bantuan}

Pada bulan Agustus 2016, dilakukan penyusunan Rancangan Anggaran Biaya (RAB) program desa organik di wilayah Jawa Barat. Proses pembuatan RAB dilakukan bersama dengan semua pihak terkait yaitu perwakilan kelompok tani, 
penyuluh, Dinas Kabupaten, dan Dinas Provinsi.

Kelompok tani penerima manfaat harus membuat Rencana Usaha Kelompok (RUK). Setelah penyusunan RUK selesai, kemudian dikumpulkan ke pemerintah provinsi. RUK tersebut dijadikan acuan dalam pembuatan Rencana Anggaran Biaya (RAB) dana bantuan di tingkat provinsi. Pemerintah provinsi kemudian menentukan jumlah dana dan volume/kuantitas barang yang harus dibeli oleh masing-masing kelompok tani. Setelah selesai, masing-masing kelompok tani harus membelanjakan dana bantuan sesuai dengan RUK yang ada. Rincian barang dalam RUK Kelompok Tani Sarinah Organik lebih detail dapat dilihat pada Tabel 2.

Di Kelompok Tani Sarinah Organik, proses pencairan dana bantuan dilakukan 2 kali dengan rincian pencairan dana bantuan yang pertama sebesar $70 \%$ kemudian $30 \%$ sisanya pada pencairan tahap kedua. Untuk pencairan dana tahap pertama dilakukan pada bulan September 2016. Kemudian untuk pencairan tahap kedua dilakukan pada bulan November 2016 atau dapat dilakukan setelah dana pada tahap pertama telah dimanfaatkan sepenuhnya.
Tabel 2. Rincian dalam RUK Kelompok Tani Sarinah Organik

\begin{tabular}{|c|c|}
\hline No & Kegiatan dan Barang \\
\hline $\mathbf{I}$ & Tahap Persiapan \\
\hline 1 & Pelatihan Anggota Kelompok \\
\hline 2 & $\begin{array}{l}\text { Pembuatan Bak Saringan } 0,1 \% \text { dari luas } \\
\text { areal }\end{array}$ \\
\hline 3 & Pupuk Organik Padat \\
\hline 4 & Benih \\
\hline 5 & Selang Effect 6 Inc \\
\hline 6 & Power Sprayer isi 15 liter \\
\hline 7 & $\begin{array}{l}\text { Komposter (Rotary } \quad \text { Klin } \quad \text { Manual } \\
\text { Biophosko) }\end{array}$ \\
\hline 8 & Aktivator Kompos \\
\hline 9 & Penggembut (Green Posko) \\
\hline 10 & Drum Plastik \\
\hline 11 & Aerator \\
\hline 12 & Caplak Besik \\
\hline 13 & PH Meter \\
\hline II & Tahap Perawatan \\
\hline 1 & Mesin Pembabat Rumput \\
\hline III & Pasca Panen \\
\hline 1 & Terpal (ukuran 8x10 m²) \\
\hline 2 & Terpal $\left(5 \times 6 \mathrm{~m}^{2}\right)$ \\
\hline 3 & Palet ukuran 110 x $110 \times 115$ \\
\hline 4 & Mesin Vacum \\
\hline 5 & Genset $16 \mathrm{KVA}$ \\
\hline 6 & Karung \\
\hline 7 & Plastik kemasan \& Label \\
\hline
\end{tabular}

\section{Tahap Kebenaran dan Ketepatan}

\section{Pemanfaatan Dana Bantuan}

Setelah dana bantuan cair, kelompok tani membelanjakan dana tersebut sesuai dengan kebutuhan yang telah ditentukan. Harga produk di pasaran bisa berbeda dengan harga yang tertulis dalam Rencana Usaha Kelompok (RUK). Sehingga jika terjadi kekurangan, kelompok tani harus mengeluarkan dana 
sendiri untuk menutupi kekurangan tersebut. Hal ini juga berlaku jika dana bantuan yang diberikan berlebih. Kelebihan dana harus dikembalikan ke pemerintah.

Pemanfaatan dana bantuan sudah sesuai dengan RUK yang telah disusun. Walaupun terjadi perbedaan harga di lapangan dengan harga yang dianggarkan, namun perbedaan tersebut tidak terlalu signifikan. Sehingga hal ini tidak menghambat proses pelaksanaan program desa organik.

Setelah pembelanjaan dana bantuan selesai, semua barang yang telah dibeli kemudian didistribusikan kepada petani anggota. Para petani anggota mendapatkan input produksi padi organik sesuai dengan kebutuhan. Kelompok Tani Sarinah telah menyediakan keperluan produksi bagi semua petani anggota.

\section{Tahap Evaluasi dan Pelaporan Pertanggungjawaban}

Pada akhir tahapan, kelompok tani membuat laporan kegiatan pelaksanaan program. Laporan tersebut berisikan diantaranya mengenai kegiatan yang dilakukan selama proses penerapan program desa organik, catatan/bukti pembelian barang, dokumentasi pembelian barang, dan detail lainnya terkait penggunaan dana bantuan.
Selanjutanya laporan diserahkan kepada Dinas Pertanian Kabupaten Bandung.

\section{Kendala dalam Pelaksanaan Program Desa Pertanian Organik}

Dalam proses pelaksanaan program desa pertanian organik terdapat kendalakendala yang harus dihadapi oleh pelaksana program. Kendala yang muncul selama program desa organik berjalan adalah:

1) Kurangnya pengetahuan petani tentang sistem pertanian organik.

2) Kendala dalam menentukan calon petani organik.

3) Kendala dalam menentukan wilayah pengembangan organik.

4) Tidak berjalannya kegiatan pembuatan pupuk dan pestisida organik yang berkelanjutan.

\section{KESIMPULAN DAN SARAN}

\section{Kesimpulan}

Kelompok tani Sarinah Organik telah melaksanakan semua tahapan program desa pertanian organik. Mulai dari tahap sosialisasi, tahap persiapan pelaksanaan seleksi calon kelompok sasaran dan calon lokasi, tahap pengadaan dan penyaluran bantuan pemerintah, tahap kebenaran dan ketepatan pemanfaatan dana bantuan, hingga tahap evaluasi dan 
pelaporan

pertanggungjawaban.

Sertifikasi organik bagi wilayah pengembangan telah diajukan, dan sertifikat keluar pada tanggal 6 Maret 2018. Program desa pertanian organik berbasis pangan telah dilaksanakan dengan baik oleh kelompok tani Sarinah Organik. Hal ini dilihat dari bertambah luasnya lahan tersertifikasi yaitu sebesar 18,337 hektar dan jumlah petani organik sebanyak 44 orang.

Selama proses pelaksanaan program desa pertanian organik terdapat 4 kendala yang dihadapi oleh pelaksana program, yaitu kurangnya pengetahuan petani tentang sistem pertanian organik, kendala dalam menentukan calon petani organik, kendala dalam menentukan wilayah pengembangan organik, dan tidak berjalannya kegiatan pembuatan pupuk dan pestisida organik yang berkelanjutan.

\section{Saran}

Saran yang bisa turut dimasukkan ke dalam penelitian ini yaitu ketua kelompok tani beserta anggota pengurus lainnya mampu terus berperan aktif dalam menyelesaikan berbagai masalah yang muncul dan dialami oleh petani. Seperti memberikan motivasi dan pemahaman bagi petani agar tetap menjalankan sistem pertanian organik secara konsisten dan berkelanjutan. Kemudian diharapkan penyuluh mampu meningkatkan bentuk pembinaan untuk memotivasi petani agar lebih berminat, bekerjasama dan berprestasi di kelompok tani sehingga pertanian organik yang dilakukan dapat berjalan secara berkelanjutan.

\section{DAFTAR PUSTAKA}

Andoko, Agus. 2002. Budidaya Padi Secara Organik. Penebar Swadaya. Jakarta.

Badan Standarisasi Nasional. 2013. Sistem Pertanian Organik SNI 6729: 2013.

Bratanova, B., Vauclair, C. M., Kervyn, N., Schumann, S., Wood, R., \& Klein, O. 2015. Savouring morality. Moral satisfaction renders food of ethical origin subjectively tastier. Appetite, 91, 137-149

Direktorat Jenderal Hortikultura Kementerian Pertanian. 2016. Petunjuk Teknis Fasilitasi Penumbuhan dan Pengembangan Desa Organik Berbasis Hortikultura.

Direktorat Jenderal Pangan Kementerian Pertanian. 2016. Pengembangan Desa Pertanian Organik Padi Tahun 2016.

Direktorat Jenderal Hortikultura Kementerian Pertanian. 2015. Pedoman Teknis Pengembangan Desa Pertanian Organik Berbasis Komoditas Perkebunan Tahun 2016.

Gunawan, Imam. 2013. Metode Penelitian Kualitatif. Jakarta: Bumi Aksara.

IFOAM. 2005. Prinsip-Prinsip Pertanian Organik. In : IFOAM General Asembly.

Sutanto, Rachman. 2002. Penerapan Pertanian Organik: Pemasyarakatan dan Pengembangannya. Kanisius. 
Sutanto, Rachman. 2002. Pertanian Organik: Menuju Pertanian Alternatif dan Berkelanjutan. Kanisius.

Silalahi, Gabriel Amin. 2003. Metodologi Penelitian dan Studi Kasus. Sidoarjo: Citra Media.
Sugiyono. 2012. Metode Penelitian Kuantitatif Kualitatif dan RND. Bandung : Alfabeta.

Wahab, Rochmat. 2014. Metodologi penelitian kualitatif.

Yanti, R. 2005. Aplikasi Teknologi Pertanian Organik: Penerapan Pertanian Organik. 